\title{
A Novel Proviral Clone of HIV-2: Biological and Phylogenetic Relationship to Other Primate Immunodeficiency Viruses
}

\author{
FRANK KIRCHHOFF, ${ }^{*}, 1$ KLAUS DIETER JENTSCH, ${ }^{*}$ BARBARA BACHMANN, * ANDREAS STUKE, * \\ CARINE LALOUX, ${ }^{*}$ WOLFGANG LÜKE, ${ }^{*}$ CHRISTIANE STAHL-HENNIG, ${ }^{*}$ JOSEF SCHNEIDER, ${ }^{*}$ \\ KATIA NIESELT, I MANFRED EIGEN, † AND GERHARD HUNSMANN* \\ *Deutsches Primatenzentrum, D-3400 Göttingen, Kellnerweg 4, and TMax Planck-Institut für Biophysikalische Chemie, \\ D-3400 Göttingen, Am Fassberg, Federal Republic of Germany
}

Received December 27, 1989; accepted March 15, 1990

\begin{abstract}
Infectious molecular clones of the human immunodeficiency virus type 2 (HIV-2) will be valuable tools for the study of regulatory gene functions and the development of an animal model for the human acquired immunodeficiency syndrome (AIDS). To this end, we have cloned and sequenced a novel HIV-2 isolate, HIV-2 ${ }_{\mathrm{BEN}}$. One clone, designated MK6, is infectious for various human T-cell lines and for human and macaque peripheral blood lymphocytes (PBL), allowing molecular studies of HIV-2 infection and replication. Since MK6 is highly cytopathic in MT-2 and Molt- 4 clone 8 cells, antiviral agents and neutralizing sera may be tested. Cluster analysis of HIV-1, HIV-2, and simian immunodeficiency virus (SIV) env and gag genes revealed that HIV-2 ${ }_{B E N}$ yielded the earliest node of phylogenetic divergence for all reported HIV-2 sequences. Noise analysis showed that, with the current data, no specification of any branching order can be made among the four groups of primate lentiviruses, HIV-1, HIV-2/SIV SMM/MAC $_{\text {, SIV }}$ AGM, and SIV $_{\text {MND. } 1990 \text { Academic }}$ Press, Inc.
\end{abstract}

\section{INTRODUCTION}

Like HIV-1 (Barré-Sinoussi et al., 1983), HIV-2 (Clavel et al., 1986a) may cause characteristic AIDS symptoms and fatal immunodeficiency (Clavel et al., 1987), but it has been suggested that HIV-2 often causes less severe disease (Marlink et al., 1988). In rare cases, HIV-2 may also induce a state in which neurological symptoms predominate (Klemm et al., 1988). Phylogenetically HIV-2 is related to SIV isolated from rhesus macaques (Macaca mulatta) (Daniel et al., 1985) and sooty mangabeys (Cercocebus atys) (Fultz et al., 1986) and it has been suggested that HIV-2 and SIV MAC $_{\text {may }}$

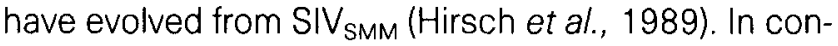
trast to HIV-1 which is only capable of infecting chimpanzees and gibbons, but without inducing disease (Alter et al., 1984; Morrow et al., 1989), several SIV isolates cause AIDS-like symptoms in macaques (Murphey-Corb et al., 1986; Daniel et al., 1987; McClure et al., 1989). Recently, it has been demonstrated that vaccination can prevent intection in monkeys (Desrosier et al., 1989; Murphey-Corb et al., 1989). Since HIV2 infects macaques (Dormont et al., 1989; Stahl-Hennig et al., submitted for publication) it could be of value in the establishment of an animal model for human AIDS.

We have isolated a biologically active molecular clone of HIV- $2_{\mathrm{BEN}}$ and studied its biological and immu-

\footnotetext{
${ }^{1}$ To whom requests for reprints should be addressed.
}

nological features in human T-cell lines as well as in macaque and human PBL. We have also started to investigate the infectivity of the molecular clone for macaques in order to establish an animal model for vaccination and therapeutic studies. The complete sequencing of the proviral DNA made it possible to determine the phylogenetic position of HIV- $2_{\mathrm{BEN}}$ in relation to the other primate lentiviruses.

\section{MATERIALS AND METHODS}

\section{Cloning and nucleotide sequence analysis}

The origin, isolation, and restriction mapping of HIV$2_{B E N}$ has been described elsewhere (Klemm et al., 1988; Schneider et al., in press). A $\lambda$ phage library was constructed from the genomic DNA isolated from Molt4 clone 8 cells infected with HIV-2 $2_{B E N}$, as described for HIV-2 ${ }_{\text {NIHZ }}$ (Franchini et al., 1989). About $3.5 \times 10^{6}$ recombinant plaques were screened $\left(T_{\mathrm{m}}=-25^{\circ}\right)$ with the pROD4.8 and pSPE2 inserts (Clavel et al., 1986b) as probes. Six positive clones were plaque purified and analyzed by restriction mapping (Fig. 1). A set of overlapping restriction fragments of MK2 and MK6 was subcloned into the $M 13 \mathrm{mp} 18$ and $M 13 \mathrm{mp} 19$ vectors (Messing and Viera, 1982) and both strands of the HIV$2_{\mathrm{BEN}}$ genome were sequenced by the dideoxynucleotide chain termination method (Sanger et al., 1977). The nucleic acid sequence data were submitted to the Los Alamos HIV Sequence Database (G. Myers). 


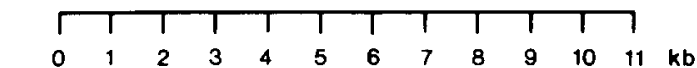

A
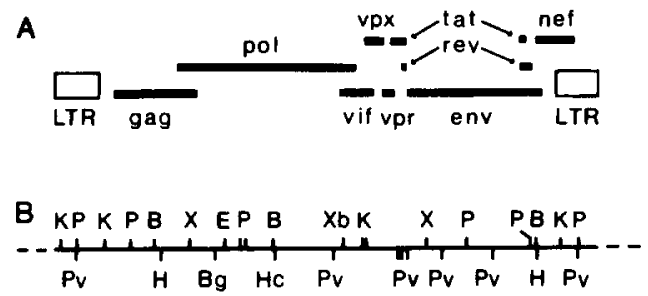

C

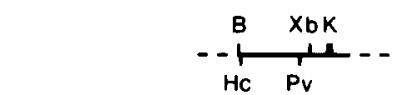

MK1
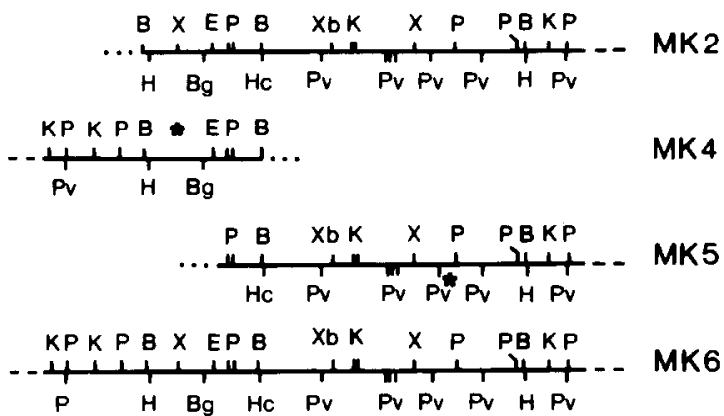

Fig. 1. Genomic organization (A) and restriction site maps of the provirus (B) and of five HIV-2 $2_{B E N}$ molecular clones (C). Restriction enzymes are BamHI (B), Bgfll (Bg), EcoRl (E), Hindlll (H), Hincll (Hc), Kpnl $(\mathrm{K})$, Pstl ( $(\mathrm{)})$, Pvull (PV), Xhol (X), and Xbal (Xb). Cellular UNA sequences are indicated by broken lines. EMBL-3 vector DNA is indicated by dotted lines. Stars indicate restriction site polymorphism among the molecular clones. The clone MK3 contains the same part of the proviral HIV-2 $2_{B E N}$ genome as MK2.

\section{Transfection of MK6 to human T-cell lines}

About $3 \times 10^{6}$ Molt- 4 clone 8 or MT-2 cells were transfected with $10 \mu \mathrm{g}$ MK6 phage DNA by the DEAEdextran method (Sompayrac and Danna, 1981; Milman and Herzberg, 1981). The RT assay was performed according to standard procedures (Hoffmann et al., 1985).

\section{Infection of human and macaque PBL}

For infection, $1 \times 10^{6} \mathrm{PBL}$ were incubated for $1 \mathrm{hr}$ in cell-free supernatant of MK6-transfected Molt-4 clone 8 cells (RT activity $1 \times 10^{6} \mathrm{cpm}$ ), washed twice with serum-free RPMI1640 (GIBCO-BRL, Karlsruhe, FRG), and cultivated with RPMI 1640 medium supplemented with 20\% FCS (Seromed, Berlin, FRG) and 10\% IL-2 (Biotest Diagnostics, Dreieich, FRG). Six days after infection an equal number of fresh PBL was added and 4 days later cocultivation with Molt- 4 clone 8 cells was begun.

\section{Western blot analysis}

For Western blotting (Towbin and Gordon, 1984), virus from cell culture supernatants was pelleted for 1 $\mathrm{hr}$ at $80,000 \mathrm{~g}$. Protein $(10 \mu \mathrm{g})$ from each pellet was separated by electrophoresis on $8-12 \%$ continuous gradient polyacrylamide gels and transferred to nitrocellulose filters (Schleicher \& Schüell, Dassel, FRG). Blots were developed using serum from a rhesus monkey experimentally infected with HIV-2 $2_{\mathrm{BCN}}$ and a rabbit antiserum against purified SIV $_{\text {AGM }}$ P24.

\section{Polymerase chain reaction (PCR)}

For PCR analysis (Ou et al., 1988) $1 \mu \mathrm{g}$ of cellular DNA trom the cell cultures indicated or $0.1 \mathrm{ng}$ MK6 DNA was dispensed into $100 \mu$ l of reaction buffer 67

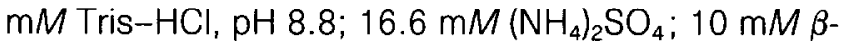
mercaptoethanol; $0.5 \%$ DMSO; $0.17 \mathrm{mg} / \mathrm{ml} \mathrm{BSA} ; 4$ $\mathrm{mMMgCl}$ ); $50 \mathrm{pM}$ of each primer 1 and 2; $2.5 \mathrm{U}$ Taq polymerase (New England Biolabs); $300 \mu M$ dNTP (Pharmacia, Uppsala, Sweden) and subjected to $35 \mathrm{cy}-$ cles of amplification using a Biomed PCR processor. One cycle consisted of $1.5 \mathrm{~min}$ at $95^{\circ}, 2 \mathrm{~min}$ at $46^{\circ}$, and $1.5 \mathrm{~min}$ at $70^{\circ}$. The first denaturation step was prolonged to $6.5 \mathrm{~min}$ and the 35th extension step, to $7.5 \mathrm{~min}$. DNA samples were separated on a $2 \%$ agarose gel.

\section{Sequence analysis of HIV-2 ${ }_{\mathrm{BEN}}$}

The phylogenetic tree was constructed using the hierarchial cluster method "average linkage." The computations were done with the CLUSTAN software package (D. Wishart) on an IBM 3090. Pairwise Hamming distances (Hamming, 1950) in the purine/pyrimidine space were determined after alignment of the env and gag nucleotide sequences using the program GAP of the UWCG software package. Since deletions and insertions were excluded from the further computations, a total of 1992 positions of the aligned env sequences were analyzed. The height of the shaded area in Fig. 4A refers to the arithmetic average box dimension in Fig. 4B. The exact geometry in the purine/pyrimidine space was determined for the four env sequences that are the most diverged (i.e., inhabiting overall the largest Hamming distances in the computed pair-distance matrix) using a method that combines both horizontal and vertical sequence analysis (Eigen et al., 1988). The box dimensions as well as the protrusion lengths are given in exact positions. All sequences except the HIV-2 $2_{\text {BEN }}$ and the HIV-1 $1_{23 U}$ (now called HIV$1_{\text {HAN } 2}$; Sauermann et al., in press) sequences were derived from the Los Alamos HIV Sequence Database (G. Myers).

\section{RESULTS}

\section{Molecular cloning and genomic organization of HIV-2 $\mathrm{BEN}$}

The restriction enzyme pattern of the six HIV - $2_{\text {BEN }}$ clones obtained (Fig. 1C) is considerably different from 
A

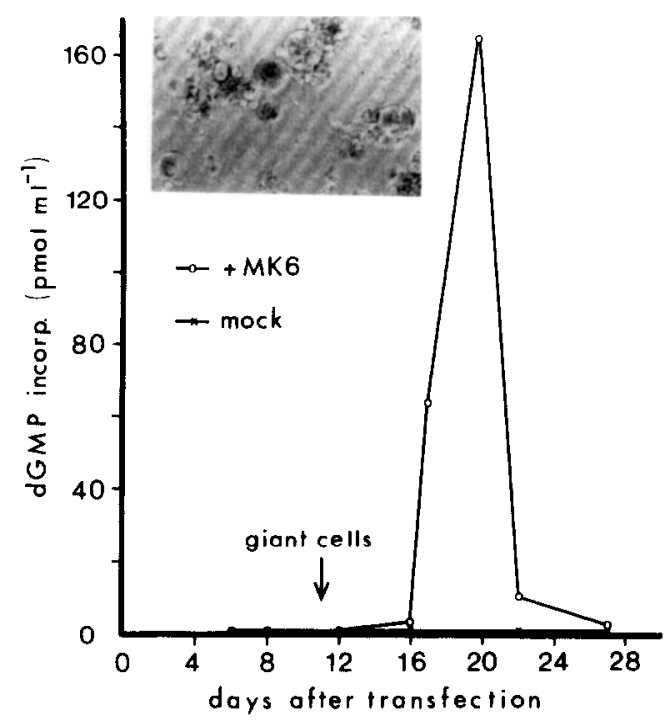

B

12

$K 123$

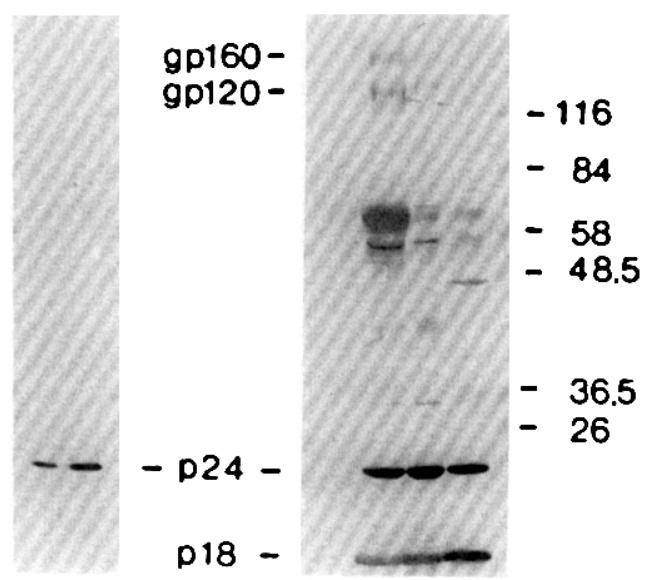

FIG. 2. Biological activity of MK6. (A) RT activity in Molt-4 clone 8 cells transfected with MK6. RT activity is monitored as [ $\left.{ }^{32} \mathrm{P}\right] \mathrm{dGMP}$ incorporation using poly(rC):oligo(dG) as the template primer. Inset: Syncytia formation in transfected Molt-4 clone 8 cells. (B) Western blot analysis of virus purified from the cell-free supernatant of Molt-4 clone 8 (lane 1) and MT-2 (lane 2) cells transfected with MK6. In lane 3 protein of the wild-type HIV-2 $2_{\text {BEN }}$ virus was separated; $K$, virus has been harvested from the supernatant of mock-transfected MT-2 cells with high background $\mathrm{RT}$. Left, a rabbit antiserum to purified SIV $\mathrm{V}_{\text {AGM }}$ p24 and, right, a serum from a rhesus monkey experimentally infected with HIV-2 $2_{\text {BEN }}$ was used.

those of previously analyzed HIV-2 proviruses (Guyader et al., 1987; Zagury et al., 1988; Franchini et al., 1989; Kong et al., 1988; Kühnel et al., 1989). The com- plete proviral HIV-2 $2_{\mathrm{BEN}}$ sequence of 10.359 nucleotides was obtained from the clones MK2 (bases 1903 to 5857 and 7293 to 10359) and MK6 (bases 1 to 1902, 5858 to 7292 , and 9132 to 10359 ). The 1227 bases of the $3^{\prime}$ region of MK2 and MK6 differed only in four bases. In genetic organization, HIV-2 $2_{\mathrm{BEN}}$ (Fig. 1A) is similar to other HIV-2 isolates (Guyader et al., 1987; Zagury et al., 1988; Franchini et al., 1989). A detailed analysis of the HIV- $2_{\mathrm{BEN}}$ sequence will be published elsewhere (Kirchhoff et al., submitted for publication).

\section{MK6 is infectious in human T-cell lines}

Eleven days after transfection of Molt-4 clone 8 and MT-2 cells with MK6 DNA syncytia formation occurred in both cell lines, and high RT activity was present in the cell culture supernatants (Fig. 2A). The viral proteins gp160, gp120, gp42, p24, and p18 could be detected in the respective culture supernatants (Fig. 2B). Southern blot analysis revealed that for both cell lines the amount of integrated proviral MK6 DNA considerably exceeded that detected after infection of the same cells with the original HIV-2 $2_{B E N}$ isolate (data not shown). Since the permanent production of MK6 virus readily caused cell death, transfected cultures had to be supplemented with uninfected cells every 2 to 3 days. In one MK6-transfected Molt-4 clone 8 cell culture neither RT activity nor cytopathic effects were observed

\section{TABLE 1}

INFECTIVITY OF MK6 fOR HUMAN T-CELL LINES, and Human and Macaque PBL

\begin{tabular}{lccc}
\hline \multicolumn{1}{c}{ Cell line } & $\begin{array}{c}\text { Peak of } \\
\text { maximal RT } \\
\text { afterinfection }\end{array}$ & $\begin{array}{c}\text { RT activity } \\
\text { (pmol dGMP } \\
\text { incorp. mi })^{-1} \text { ) }\end{array}$ & $\begin{array}{c}\text { Maximal } \\
\text { activity in } \\
\text { uninfected cells }\end{array}$ \\
\hline Molt-4 clone 8 & 9 & 110.4 & 0.9 \\
MT-2 & 10 & 60.2 & 15.8 \\
CEM & 23 & 9.4 & 0.6 \\
HUT-78 & 37 & 5.5 & 0.7 \\
hurkat & 16 & 3.1 & 0.6 \\
Human PBL & 18 & 6.8 & 0.1 \\
Cynomolgus PBL & $7^{a}$ & 6.4 & 0.2 \\
Rhesus PBL & $7^{a}$ & 7.0 & 0.2 \\
\hline
\end{tabular}

Note. Human T-cell lines were infected with $1 \times 10^{6} \mathrm{cpm}$ RT activity of MKG virus as described for the infection of PBL under Materials and Methods. In MT-2 cell supernatants high background RT activity was measured owing to the fact that this cell line carries the HTLV1 provirus (Harada et al., 1985).

${ }^{a}$ Macaque $\mathrm{PBL}$ were cocultivated with Molt-4 clone 8 ten days after infection since they were too sensitive for longer independent cultivation. Therefore, the RT values shown may not represent the real peak activity. All infections were repeated two to five times with similar results. 


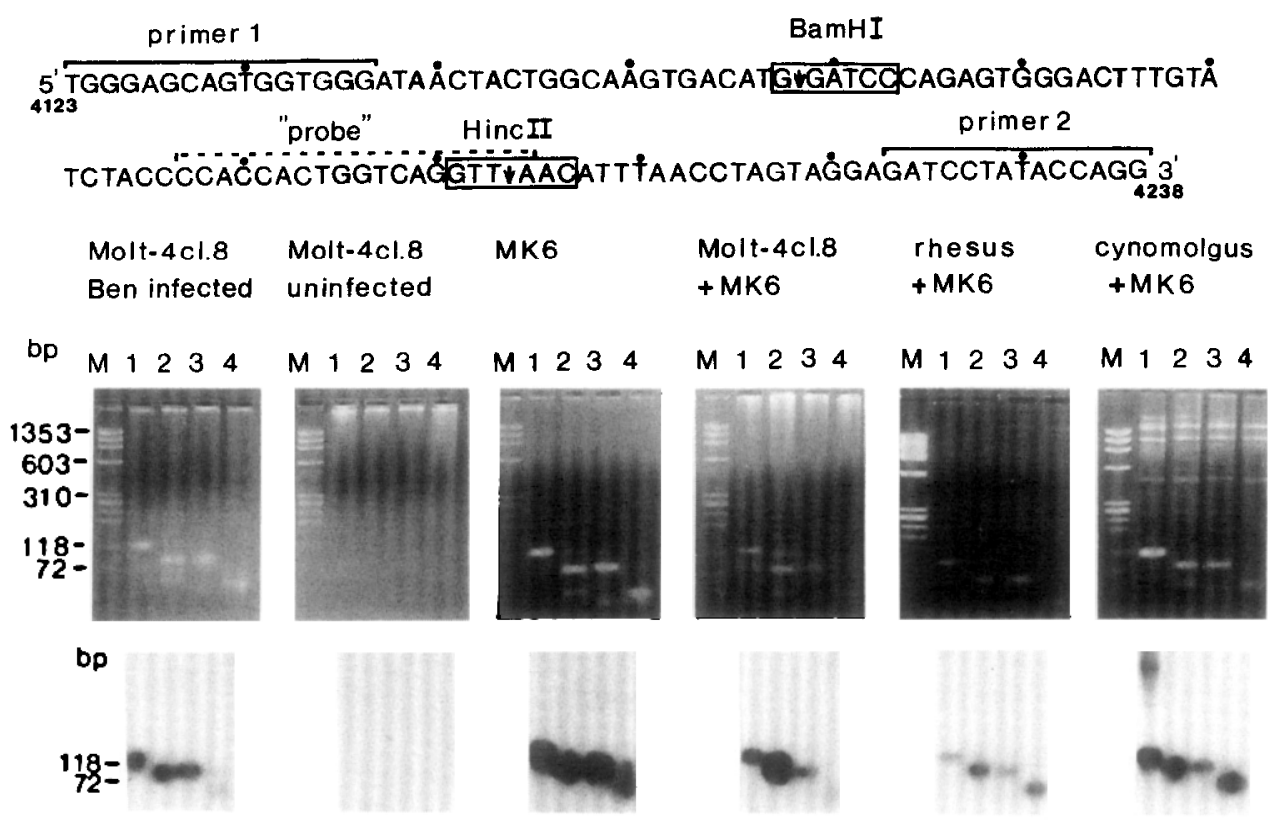

FIG. 3. Detection of proviral sequences by PCR. Above, the amplified DNA sequence of the HIV-2 $2_{B E N}$ genome is noted. The primer sequences, the radioactively labeled probe, and restriction enzyme recognition sites used are indicated. Middle, agarose gels with amplified DNA fragments and bottom Southern blots of the same gels. (M) Marker ( $\phi$ X174Haell digested, New Fngland Biolabs Inc., Beverley, USA); lane 1, undigested DNA; 20- $\mu$ l aliquots of amplified DNA were digested with BamHI (lane 2), Hincll (lane 3), and BamHI and Hincll together (lane 4).

6 weeks after transfection. However, substantial amounts of proviral DNA were still present after 2 months of culture and the addition of uninfected cells leads to renewed giant cell formation and virus release.

To examine the cell tropism of MK6, Jurkat, CEM-T4, and HUT-78 cells were infected with culture supernatant from transfected Molt-4 clone 8 cells. In these three cell lines MK6 replicated less efficiently than in Molt- 4 clone 8 or MT-2 cells (Table 1). In contrast to infected MT-2 and Molt- 4 clone 8 cells, where the RT peak was reached 9 to 10 days after infection, the HUT. 78, CEM-T4, and Jurkat cell lines showed maximal RT values 2 to 5 weeks after infection (Table 1). Southern blot and PCR analysis revealed the presence of relatively low amounts of MK6 provirus in the host cell genomes (data not shown). Furthermore, little or no cytopathic effects were observed in these three cell lines.

\section{MK6 is highly infectious for macaque and human PBL}

Eighteen days after infection of human PBL peak RT activity was present in the cell-free supernatants (Table 1). After cocultivation with uninfected Molt-4 clone 8 cells giant cell formation and high RT values of about $60 \mathrm{pmol}$ dGMP incorporation per milliliter of supernatant were observed. The infection of macaque PBL with MK6 proceeds much faster. Seven days after infection of rhesus and fascicularis macaque PBL, RT activities comparable to the peak activity observed in infected human PBL culture supernatants were detected in both cultures (Table 1). Since macaque PBL were very sensitive, subsequent cocultivation with Molt-4 clone 8 cells was necessary. About 10 days later the RT values increased to about $75 \mathrm{pmol}$ dGMP incorporated per milliliter of supernatant. MK6 proviral DNA in these cultures was detected by PCR analysis (Fig. 3).

\section{The phylogenetic position of HIV-2 $2_{B E N}$}

To investigate the phylogenetic position of HIV- $2_{B E N}$ relative to other HIV-2 and SIV isolates, evolutionary trees were constructed from the DNA sequences of the env (Fig. 4A) and gag (not shown) genes. The branching order is consistent for both genes and also for different methods of evaluation of the pair-distance matrix (i.e., using transversions only, as well as both weighted and unweighted transitions and transversions). The diagram indicates that HIV- $2_{B E N}$ has branched off the main stem earlier than the HIV-2 isolates previously described. From the groups HIV-1, HIV-2, and SIV, the four sequences furthest diverged from their assumed common precursor were compared by using a method of noise analysis (Eigen et al., 1988) (Fig. 4B). The diagram reveals a bundle-like topology since the three box dimensions are of almost equal magnitude. All four groups of HIV and SIV (HIV1, HIV-2/SIV SMMMAC $_{\text {, SIV }}$ AGM, and SIV ${ }_{\text {MND }}$ ) branch off in- 


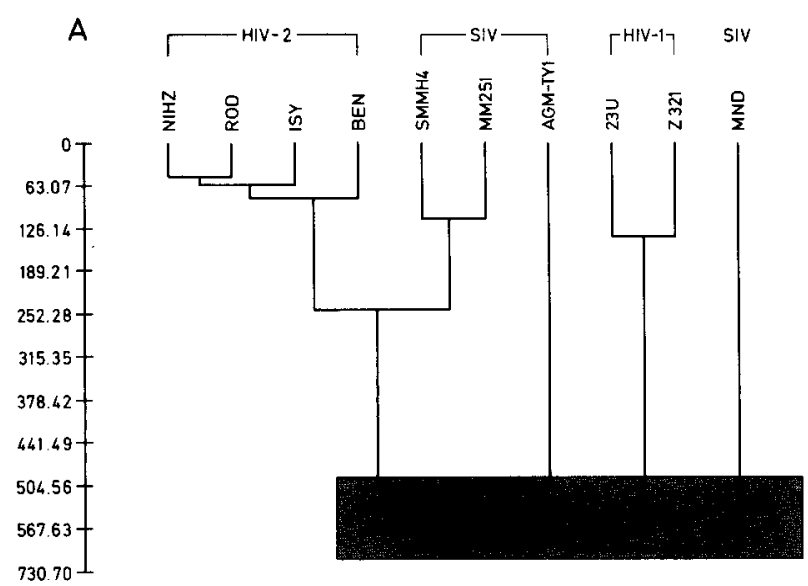

B

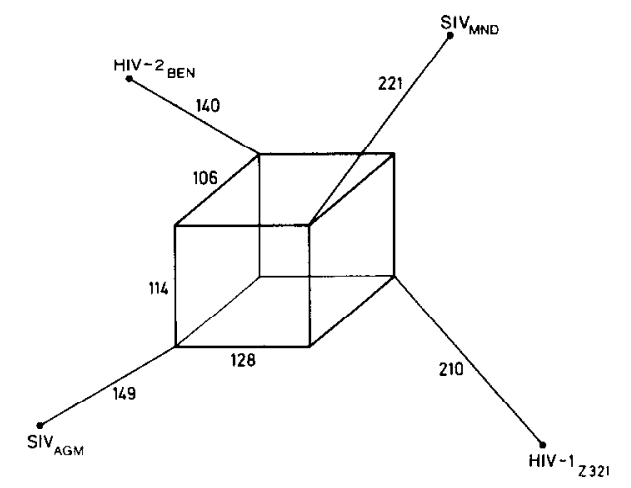

FIG. 4. Comparative sequence analysis of HIV-1, HIV-2, and SIV based on the env DNA sequences in the purine/pyrimidine space (1992 base positions considered). (A) Phylogenetic tree derived by cluster analysis. In the scale the number of diverged base positions is given. Therefore, the distance in sequence positions between any two isolates is twice the distance along the ordinate to the connecting node. (B) Exact geometry of the four most diverged sequences. Numbers refer to exact positions as described by Eigen et al. (1988).

side the shaded area in Fig. 4B. We therefore conclude that there exists a common node for the four groups, which lies within the box. The classical tree construction methods usually yield a definite order of even the early branching nodes (Smith et al., 1988; Tsujimoto et al., 1989). However, the present analysis shows that due to noise accumulation, the existing data are not sufficient to specify the early branching order of HIV-1, HIV-2/SIV $V_{\text {SMM } / M A C}$, SIV $_{A G M}$, and SIV $V_{\text {MND }}$.

\section{DISCUSSION}

In the present study we describe the biological properties and the phylogenetic position of a new HIV-2 proviral clone.

The varying biological properties of HIV-2 isolates, such as replication rates, cytopathogenicity, and cell tropism may have relevance to the different degrees of pathogenicity in humans (Kong et al., 1988; Kühnel et al., 1989). Another HIV-2 isolate from a patient with neurological disorders, HIV-2 ${ }_{\mathrm{D} 194}$ (Kühnel et al., 1989), grows slowly with little or no syncytia formation in HUT78 cells. Our data show that those findings could not be generalized for other human T-cell lines.

Inexpensive and efficient animal models are necessary for the development of protective vaccines against HIV infection. To date, only macaques infected with various SIV isolates have developed AIDS-like symptoms (Daniel et al., 1987; McClure et al., 1989), while the pathogenicity of HIV-2 for macaques is still a subject of discussion (Letvin et al., 1987; Dormont et al., 1989). Nevertheless, clinical alterations in HIV-2-infected macaques have been described (Dormont et al., 1989) and the duration of the animal studies conducted so far may be too short to exclude a subsequent appearance of AIDS-like symptoms. Therefore, the development of an animal model with a well-characterized molecular clone of a human virus, highly re-

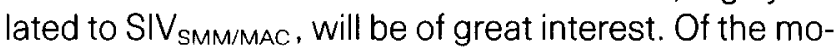
lecular HIV-2 clones described previously (Naidu et al., 1988; Zagury et al., 1988), only the HIV-2 SBLISY clone (Franchini et al., 1989) has been reported to be infectious for macaque PBL and macaques, though the data have yet to be published.

We have shown that MK6 reproducibly replicates in the PBL of rhesus and cynomolgus macaques. Preliminary data has proven that MK6 is also infectious for cynomolgus monkeys. Inoculation of cell-free MK6 virus in two animals led to seroconversion 4 weeks postinoculation and viremia in one animal (data not shown).

The MK6 clone has several interesting biological features and provides us with many opportunities for future study. It is highly cytopathic and blocks proliferation in Molt-4 clone 8 and MT-2 cells. Therefore, antiviral agents and neutralizing sera can be tested in vitro. Since MK6 is infectious not only in human and macaque PBL, but also for macaques, we will investigate the influence of the negative regulatory nef protein (Guy et al., 1987) on the in vitro and in vivo pathogenicity of HIV-2. To examine the genetic evolution of the HIV-2 genome, we have begun to determine the in vivo and in vitro mutation rates of MK6 by PCR analysis.

\section{ACKNOWLEDGMENTS}

We acknowledge the excellent technical assistance of $E$. Gerlach, D. Schreiner, R. Jung, M. Stäger, C. Oeffner, and S. Strempel. We also thank Dr. M. Alizon for providing the HIV-2 $2_{\mathrm{ROD}}$ subclones, Dr. J. Mous for help with sequencing of HIV-2 $2_{B E N}$ gag and po/ genes, and Dr. A. Flemming, A. Frutkin, and R. Turner for reviewing this manuscript. This publication contains parts of the PhD theses of $F$. Kirchhoff and B. Bachmann.

Note added in proof. After submission of our manuscript to Viro/ogy a further HIV-2, called HIV-2 $2_{\mathrm{ALT}}$, which has branched off the main stem of HIV-2 earlier than HIV-2 $2_{B E N}$ has been published. (Dietrich U. et al., 1989, Nature 342; 948-950.) 


\section{REFERENCES}

Alter, H. J., Eichberg, J. W., Masur, H., Saxinger, W. C., Gallo, R. C., MACHER, A. M., LANE, H. C., and FAUCI, A. S. (1984). Transmission of HTLV-III infection from human plasma to chimpanzees: An animal model for AIDS. Science 226, 549-552.

Barré-Sinoussi, F., Chermann, J. C., Rey, F., Nugeyre, M. T., Chamaret, S., Gruest, J., Dauguet, C., Axler-Blin, C., Brun-Vézinet, F., Rouzioux, C., Rozenbaum, W., and Montagnier, L. (1983). Isolation of a T-lymphotropic retrovirus from a patient at risk for acquired immunodeficiency syndrome (AIDS). Science 220, 868871.

Clavel, F., Guétard, D., Brun-Vézinet, F., Chamaret, S., Rey, M. A., Santos-Ferreira, M. O., Laurent, A. G., Dauguet, C., Katlama, C., Rouzioux, C., Klatzmann, D., Cliampalimaud, J. L., and MonTAGNIER, L. (1986a). Isolation of new human retrovirus from West African patient with AIDS. Science 233, 343-346.

Clavel, F., Guyader, M., Guétard, D., Salle, M., Montagnier, L., and ALIZON, M. (1986b). Molecular cloning and polymorphism of the human immunodeficiency virus type 2. Nature (London) 324 , 691-695.

Clavel, F., Mansinho, K., Chamaret, S., Guétard, D., Favier, V., Nina, J., Santos-Ferreira, M. O., Champalimaud, J. L., and MonTAGNIER, L. (1987). HIV-2 infection associated with AIDS in West Africa. N. Engl. J. Med. 316, 1180-1185.

Daniel, M. D., Letvin, N. L., King, N. W., Kannagi, M., Sehgal, P. K., Hunt, R. D., KankI, P. J., EsSeX, M., and Desrosiers, R. C. (1985). Isolation of T-cell tropic HTLV-III-like retrovirus from macaque. Science 228, 1201-1204

Daniel, M. D., Letvin, N. L., Sehgal, P. K., Hunsmann, G., Schmidt, D. K., KING, N. W., and DESROSIERS, R. C. (1987). Long-term persistent infection of macaque monkeys with the simian immunodeficiency virus. J. Gen. Virol. 68, 3183-3189.

Desrosier, R. C., Wyand, M. S., Kodama, T., Ringler, D. J., Arthur, L. O., Sehgal, P. K., Letvin, N. L., King, N. W., and Daniel, M. D. (1989). Vaccine protection against simian immunodeficiency virus infection. Proc. Natl. Acad. Sci. USA 86, 6353-6357.

Dormont, D., Livartowski, J., Chamaret, S., Guétard, D., Henin, D., Levagueresse, R., van der MoORTelle, P. F., LaRke, B., Gourmelon, P., Vazeux, R., Metivier, H., Flageat, J., Court, L., Hauw, J. J., and MONTAGNIER, L. (1989). HIV-2 in rhesus monkeys: Serological, virological, and clinical results. Intervirology 30, 59-65.

EIgen, M. WINKLER-OSWATISCH, R., and Dress, A. (1988). Statistical geometry in sequence space: A method of quantitative comparative sequence analysis. Proc. Natl. Acad. Sci. USA 85, 59135917.

Franchini, G., Fargnoli, K. A., Giombini, F., Jagodzinski, L., De Rossi, A., Bosch, M., Biberfeld, G., renyö, E.-M., Albert, J., Gallo, R. C., and WONG-STAAL, F. (1989). Molecular and biological characterization of a replication competent human immunodeficiency type 2 (HIV-2) proviral clone. Proc. Natl. Acad. Sci. USA 86, 24332437.

Fultz, P. N., McClure, H. M., Swenson, R. B., McGrath, C. R., Brodie, A., Gretchell, J. P., Jewsen, F. C., Anderson, L. D. C., BroderSON, J. R., and FrANCIS, D. P. (1986). Persistent infection of chimpanzees by human T-lymphotropic virus typell//lymphadenopathyassociated virus: A potential model for acquired immunodeficiency syndrome. J. Virol. 58, 116-124.

Guy, B., Kieny, M. P., Riviers, Y., Le Peuch, C., DotT, K., Girard, M. MONTAGNiER, L., and LECOCQ, J. P. (1987). HIV F/3'orf encodes a phosphorylated GTP-binding protein resembling an oncogene product. Nature (London) 330, 266-269.

Guyader, M., Emerman, M., Sonigo, P., Clavel, F., Montagnier, L., and ALIZON, M. (1987). Genome organization and transactivation of the human immunodeficiency virus type 2. Nature (London) $326,662-669$.

HAMMING, R. W. (1950). Error detecting and error correcting codes. Bell. Syst. Techn. J. 29, 147-160.

HARADA, S., KOYANAGI, Y., and YAMAMOTO, N. (1985). Infection of HTLV-III/LAV in HTLV-I-carrying cells MT-2 and MT-4 and application in a plaque assay. Science $229,563-566$.

Hirsch, V. M., Olmsted, R. A., Murphey-Corb, M., Purcell, R. H., and JOHNSON, P. R. (1989). An African primate lentivirus (SIV SMM $_{\text {) }}$ closely related to HIV-2. Nature (London) 339, 389-392.

HoffMAN, A. D., BANAPOUR, B., and LEV,, J. A. (1985). Characterization of the AIDS-assnciated retrovirus reverse transcriptase and optimal conditions for its detection in virions. Virology 147, 326335.

Klemm, E., Schneeweis, K. E., Horn, R., Tackmann, W., Schulze, G., and SCHNEIDER, J. (1988). HIV-2 infection with initial neurologic manifestation. J. Neurol. 235, 304307.

Kong, L. I., Lee, S.-W., Kappes, J. C., PARKin, J. S., Decker, D., Hoxie, J. A., HAHN, H. B., and SHAW, G. M. (1988). West African HIV-2 related human retrovirus with attenuated Cytopathicity. Science $240,1525-1529$.

KüHnel, H., Von BRIESEN, H., Dietrich, U., AdAMSKI, M., Mix, D., Biesert, L., Kreuz, R., Immelmann, A., Henco, K., Meichsner, C., ANDREesen, R., Gelderblom, $H_{\text {., }}$ and RübSAMEN-WAigmanN, $H$ (1989). Molecular cloning of two West African human immunodeficiency virus type-2 isolates that replicate well in macrophages: A Gambian isolate, from a patient with neurologic acquired immunodeficiency syndrome, and a highly divergent Ghanian isolate. Proc. Natl. Acad. Sci. USA 86, 23832387.

Letvin, N. L., Daniel, M. D., Sehgal, P. K., Yetz, J. M., Solomon, K. R., Kannagi, M., SchmidT, D. K., Silva, D. P., Montagnier, L., and DesRosiers, R. C. (1987). Infection of baboons with human immunodeficiency virus-2 (HIV-2). J. Infect. Dis. 156, 406-407.

Marlink, R. G., Ricard, D., M'Boup, S., Kanki, P. J., Romet-Lemonne, J.-L., N'Doye, I., DIOP, K., SIMPSON, M. A., Greco, F., Chou, M.-J., Degrutolla, V., Hsifh, C.-C., Boyf, C., Barin, F., Denis, F., MCLANE, M. F., and Essex, M. (1988). Clinical, hematologic, and immunologic cross-sectional evaluation of individuals exposed to human immunodeficiency virus type 2 (HIV-2). AIDS Kes. Hum. Retroviruses 4, 137-148.

MCCluRe, H. M., Andergon, D. C., Fultz, P. N., Ansari, A. A., Lock WOOD, E., and BRODIE, A. (1989). Spectrum of disease in macaque monkeys chronically infected with SIV/SMM. Vet. Immunol. Immunopathol. 21, 13-24

MESSING, J., and VIERA, J. (1982). A new pair of M13 vectors for selecting either DNA strand of double digest restriction fragments. Gene $19,269-276$.

MiLmAN, G., and HFrzBERG, M. (1981). Efficient DNA transfection and rapid assay for thymidine kinase activity and viral antigenic determinants. Somat. Cell Genet. 7, 161-170.

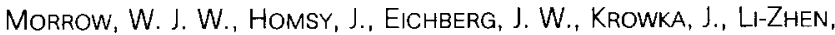
P., Gaston, I., LegG, H., LerChe, N., Thomas, J., and LeVY, J. A. (1989). Long-term observations of baboons, rhesus monkeys, and chimpanzees inoculated with HIV and given periodic immunosuppressive treatment. AIDS Res. Hum. Retroviruses 5, 233-245.

Murphey-Corb, M., Martin, L. N., Rangan, S. R. S., Baskin, G. B., Gormus, B. J., WOLF, R. H., ANDES, W. A., WEST, M., and MONTELARO, R. C. (1986). Isolation of an HTLV-III related retrovirus from macaques with simian AIDS and its possible origin in asymptomatic mangabeys. Nature (London) 321, 435-437.

Murphey-Corb, M., Martin, L. N., Davison-Fairburn, B., Miller, M. West, M., OKaWa, S., Baskin, G. B., Zhang, J-Y., PuTney, S. D. ALLISON, A. C., and EPPSTEIN, D. A. (1989). A formalin inactivated whole simian immunodeficiency virus vaccine confers protection in macaques. Science 246, 1293-1297. 
Naidu, Y. M., Kestler, H. W., LI, Y., Butler, C. V., Silva, D. P., Schmidt, D. K., Troup, C. D., Sehgal, P. K., Sonigo, P., Daniel, M. D., and DESROSIERS, R. C. (1988). Characterization of infectious molecular clones of simian immunodeficiency virus (SIVmac) and human immunodeficiency virus type 2: Persistent infection of rhesus monkeys with molecularly cloned SIVmac. J. Virol. 62(12), 4691-4696.

Ou, C. Y., KWok, S., MitChell, S. W., Mack, D. H., Sninsky, J. J., Krebs, J. W., Feorino, P., Warfield, D., and Schochetman, G. (1988). DNA amplification for direct detection of HIV-1 in DNA of peripheral blood mononuclear cells. Science 239, 295-297.

SANGer, F., NickLen, S., and Coulson, A. R. (1977). DNA sequencing with chain terminating inhibitors. Proc. Natl. Acad. Sci. USA 74, 54-63.

Sauermann, U., Schneider, J., Mous, J., Brunckhorst, U., Schedel, I., JENTSCH, K. D., and HUNSMANN, G. Molecular cloning and characterization of a German HIV-1 isolate. AIDS Res. Hum. Retroviruses, in press.

SCHNEIDER, J., LÜKE, W., KIRCHHOFF, F., JUNG, R., JURKIEWICZ, E., STAHLHenning, C., Nick, S., Klemm, E., JentsCh, K. D., and Hunsmann, G.
Isolation and characterization of HIV-2BEN obtained from a patient with predominantly neurological defects. AIDS, in press.

Smith, T. F., Srinivasan, A., Schochetman, G., Marcus, M., and My ERS, G. (1988). The phylogenetic history of human immunodeficiency viruses. Nature (London) 333, 573-575.

SOMPAYRAC, L. M., and DANNA, K. J. (1981). Efficient infection of monkey cells with DNA of simian immunodeficiency virus 40 . Proc. Natl. Acad. Sci. USA 78, 7575-7578.

TOWBIN, H., and GoRDON, J. (1984). Immunoblotting and dot immunoblotting-Current status and outlook. J. Immunol. Methods 72, 313-340.

Tsuimoto, H., Hasegawa, A., Maki, N., Fukasava, M., Miura, T., Speidel, S., CoOper, R. W., Moriyama, E. N., Gojibori, T., and HaYAMI, M. (1989). Sequence of a novel simian immunodeficiency virus from a wild-caught mandrill in Africa. Nature (London) 341. 539-541.

Zagury, J. F., Franchini, G., Reitz, M., Collati, E., Starvich, B., Hall, L., Fargnoli, K., Jadgodzinski, L., Guo, H.-G., Laure, F., ARYA, S. K., JOSEPHS, S., ZAGURY, D., and WONG-STAAL, F. (1988). Genetic variability between HIV-2 isolates is comparable to the variability among HIV type 1. Proc. Natl. Acad. Sci. USA 85, 59415945 